УДК 616.147.3-007.64-089.819: 621.791.011

\title{
Ендовенозне електрозварювання як сучасна й ефективна методика малоінвазивного лікування варикозного розширення вен великих діаметрів
}

\author{
Л.М. Чернуха, М.В. Чехлов, А.М. Рябоконь, Е.А. Столярчук
}

Национальный институт хирургии и трансплантологии им. А.А. Шалимова НАМН

Украины, Киев

Вступ. На сьогоднішній день варикозне розширення вен нижніх кінцівок $є$ принципово важливим питанням в системі охорони здоров'я більшості країн світу через свою надзвичайну поширеність, латентному прогресуючого перебігу з важкими ускладненнями і життєво небезпечними наслідками. При розробці лікувальної тактики на сьогоднішній день перевага віддається транскутанним втручанням. Еталонним методом малоінвазивного лікування $€$ ендовенозна лазерна коагуляція (ЕВЛК) з використанням діодних світловодів, яка характеризується високою результативністю при діаметрі неспроможного сегмента менше 20 мм і дозозалежним спектром ускладнень. Це обумовлює актуальність пошуку нового методу термальної абляції з меншим нагріванням тканин і більш досконалим алгоритмом управління.

Мета дослідження. Порівняти ефективність методик ендовенозного електрозварювання та лазерної абляції в лікуванні хронічної венозної недостатності нижніх кінцівок.

Матеріали та методи. Дослідження проведено на вибірці з 279 пацієнтів (178 жінок, 106 чоловіків у віковому діапазоні від 29 до 76 років) з хронічною венозною недостатністю нижніх кінцівок $\mathrm{C}_{2-6} \mathrm{E}_{\mathrm{ps}} \mathrm{A}_{\mathrm{sp}} \mathrm{P}_{\mathrm{r}}$, яким була виконана ендовенозна абляція стовбурів підшкірних вен 3 діаметрами неспроможних сегментів від 14 до 28 мм. Контрольну групу склали 192 пацієнта, яким була проведена лазерна коагуляція стовбура великої підшкірної вени за допомогою діодного світловоду 1470 нм. У основній групі (67 пацієнтів) операція проводилася за допомогою ендовенозного електрозварювання.

Ефективність лікування оцінювали з урахуванням об’єктивних та суб’єктивних даних.

Результати досліджень та їх обговорення. Усі пацієнти проходили контрольну перевірку через 7 днів, 1 та 6 місяців, і потім кожні півроку. Фізикальне обстеження і кольорове дуплексне сканування оперованої кінцівки виконувалося для оцінки якості оклюзії БПВ і можливого рефлюксу і реканалізації. 3 метою контролю якості життя пацієнтів просили заповнити анкету CIVIQ через 1 і 6 місяців після операції.

У результаті проведеного лікування через 6 місяців частота випадків часткової реканалізації стовбура великої підшкірної вени в 1 групі становила 4\%, у другій - $0 \%$ ( $>0.05$ за параметром $\chi^{2}$ ). У всіх випадках рецидиви в першій групі спостерігалися при діаметрі пригирлової ділянки судини вище 21 мм. У ранньому післяопераційному періоді з однаковою частотою спостерігалися випадки больового синдрому низької інтенсивності за ходом ВПВ. При аналізі якості життя пацієнтів за шкалою CIVIQ обидві методики є однаково ефективними.

Метод ендовенозного електрозварювання (ЕВЕ3) має більш простий принцип трансформації електричної енергії в теплову, а також можливість саморегулювання тривалості експозиції робочої поверхні електрода в просвіті вени, що дозволяє досягати оклюзії стовбурів підшкірних вен діаметром до 30 мм без появи ознак рецидиву варикозної хвороби протягом 6 місяців післяопераційного спостереження.

Висновки. ЕВЕЗ $є$ ефективним аналогом ЕВЛК з більш високим профілем безпеки і досконалим алгоритмом управління. Методика становить інтерес для подальшого наукового дослідження і практичного застосування.

EBEЗ дозволяє ефективно проводити транскутанну венектомію при варикозній хворобі нижніх кінцівок 3 діаметром неспроможного сегмента підшкірної вени від 20 до 30 мм при мінімальному спектрі ускладнень.

Вступ. На сьогоднішній день варикозне розширення вен нижніх кінцівок (ВРВНК) є принципово важливим питанням на порядку денному в системі охорони здоров'я більшості країн світу через свою надзвичайну поширеність, латентний прогресуючий перебіг з важкими ускладненнями життєво небезпечними наслідками. Вважається, що загальнопопуляційна поширеність має широку варіацію в діапазоні від 40 до 90\% [1], при цьому простежується гендерна (переважна 60-70\% поширеність серед жіночої частини населення) [2], вікова (прямий кореляційний зв'язок між показниками) [3] і соціальна (значний вплив статичного i динамічного варіантів фізичного навантаження) [4] складові кривої епідеміологічного розподілу; проте все ж основна роль у розвитку даного захворювання належить фактору генетичної схильності
[5]. Різноманітна клінічна симптоматика представлена спектром від мінімальних скарг на косметичний вигляд і дискомфортні відчуття до трофічних розладів м'яких тканин, значно знижують якість життя (ЯЖ), і потенційного тромбоутворення в просвіті вени зі зміненою гемодинамікою.

Ультразвукові методи діагностики з можливістю застосування дуплексного або триплексного режимів на даний момент є єдиним ефективним способом об'єктивного визначення стану венозного апарату нижніх кінцівок, вивчення локалізації та варіації неспроможності або оклюзії уражених сегментів, а також формування тактики комплексного лікування і профілактики подальшого прогресування [6].

При розробці лікувальної тактики на сьогоднішній день перевага надається транскутанним втру- 
чанням [7]. Еталонним методом усунення вертикального рефлюксу по магістральних стовбурах підшкірних вен визнана ендовенознатермоабляція 3 лазерним або радіочастотним принципами деструкції ендотелію [8]. Додатковими і альтернативними підходами є хімічний вплив розчинами детергентів на стінку вени і механічне пошкодження внутрішньої вистилки судини [9]. У основі всіх методів лежить незмінний принцип: фізичне або хімічне пошкодження судинної стінки, досягнення керованої тимчасової тромботичної оклюзії судинного русла 3 подальшим стійким фіброзним закриттям венозного просвіту [10]. Своє місце в арсеналі оперативних втручань має і хірургічне видалення уражених вен; втім, і в цьому випадку позначається вплив концепції «малоінвазивної флебології» [11].

Широка поширеність, латентний перебіг і небезпека даного захворювання, а також недооцінка важливості проблеми пацієнтами і медичними фахівцями загального напрямку обумовлює актуальність популяризації даного питання в клінічній і академічної практиці з метою підвищення настороженості і обізнаності про ризики і ускладнення, а також можливості діагностики, лікування і профілактики.
Мета дослідження. Порівняння результатів після проведення ендовенозної лазерної коагуляції (ЕВЛК) стовбура великої підшкірної вени (ВПВ) із застосуванням радіального світловоду 1470 нм i методики ендовенозного електрозварювання (EBE3) у пацієнтів різних вікових категорій з хронічною венозною недостатністю, обумовленою варикозним розширенням вен нижніх кінцівок, класу $\mathrm{C}_{2-6} \mathrm{E}_{\mathrm{ps}} \mathrm{A}_{\mathrm{sp}} \mathrm{P}_{\mathrm{r}}$.

Матеріали та методи. Ретроспективний аналіз 279 клінічних випадків комбінованого хірургічного лікування пацієнтів із варикозним розширенням вен нижніх кінцівок, прооперованих на базі Університетської клініки (УК) Одеського національного медичного університету за період з 2015 по 2019 pp.

Загальна вибірка сформована ретроспективно, у міру аналізу ефективності ЕВЛК великої підшкірної вени (ВПВ) з використанням радіальної лазерної оптики з 2015 року і впровадження в практику клініки ендовенозного електрозварювання 3 2018 року.

Критерії включення і виключення наведені в таблиці 1.

Таблиця 1

Критерії включення і виключення пацієнтів у дослідження

\begin{tabular}{|l|l|}
\hline \multicolumn{1}{|c|}{ Критерії включення } & \multicolumn{1}{|c|}{ Критерій виключення } \\
\hline $\begin{array}{l}\text { Пацієнти з УЗ-ознаками неспроможності під- } \\
\text { шкірних вен (рефлюкс> 500 мс) }\end{array}$ & $\begin{array}{l}\text { Пацієнти 3 рецидивом варикозної хвороби } \\
\text { ніг після оперативного лікування }\end{array}$ \\
$\begin{array}{l}\text { Пацієнти 3 клінічними проявами варикозного } \\
\text { розширення підшкірних вен гомілки }\end{array}$ & $\begin{array}{l}\text { Пацієнти 3 гіперкоагуляційними порушення- } \\
\text { ми, тромбозами глибоких вен і тромбофлебі- } \\
\text { том поверхневих вен в анамнезі }\end{array}$ \\
$\begin{array}{l}\text { Пацієнти, які мають за класифікацією СЕАР } \\
\text { групу від С2 до С6 }\end{array}$ & $\begin{array}{l}\text { Епіфасціальне розташування, розсипний тип, } \\
\text { звитий хід підшкірних вен }\end{array}$ \\
\hline
\end{tabular}

Вибірка стандартизована за віком, статтю та клінічними проявами ХВН, після чого розділена на 2 групи: 1) 192 пацієнти, яким проведена ЕВЛК неспроможного сегменти ВПВ / МПВ радіальним лазерним світловодом; 2) 87 пацієнтів, яким проведена ЕВЕ3 неспроможного сегмента підшкірної вени.

При проведенні ЕВЛК в 1 групі використовувався радіальний лазерний світловод 3 джерелом лазерного випромінювання «Ліка-хірург» в режимі постійної генерації лазерного хвилі довжиною 1470 нм при потужності 10 Вт. Для пацієнтів 2 групи застосовувалася спеціальна ендовенозна модифікація біполярного електрода для коагулятора «Свармед». Вибір конкретної методики здійснювався самим пацієнтом після детального обговорення переваг та недоліків, ознайомленням зі світовими та локальними статистичними показниками їх ефективності і можливими ризиками.
Середній віковий діапазон $(\mathrm{M} \pm \mathrm{m})$ пацієнтів:

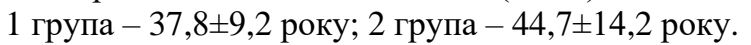

- Гендерний розподіл пацієнтів: 1 група: жінки - 136 (69\%) осіб, чоловіки - 61 (31\%) особа; 2 група: жінки - 42 (48\%) особи, чоловіки $45(52 \%)$ осіб.

- Середня довжина $(\mathrm{M} \pm \mathrm{m})$ неспроможного субфасціального сегмента ВПВ: 1 група - 376 441 мм; 2 група - 334 \pm 29 мм.

- Середня довжина $(\mathrm{M} \pm \mathrm{m})$ неспроможного суб-

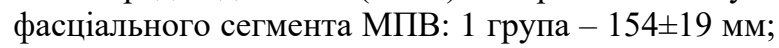
2 група $-171 \pm 14$ мм.

- Середній пригирловий діаметр неспроможною підшкірної вени: 1 група - [8-24] мм $(\mathrm{M} \pm \mathrm{m}=15,7 \pm 3,8 \quad$ мм$) ; 2$ група - [17-28] мм $(\mathrm{M} \pm \mathrm{m}=22,1 \pm 1,8 \mathrm{MM})$.

Розподіл пацієнтів за шкалою СЕАР наведений в таблиці 2 . 
Розподіл пацієнтів за шкалою СЕАР

\begin{tabular}{|l|l|l|l|}
\hline & 1 група & 2 група & Всього \\
\hline C2 & $75(39 \%)$ & $23(27 \%)$ & $98(35 \%)$ \\
\hline C3 & $81(42 \%)$ & $38(44 \%)$ & $119(43 \%)$ \\
\hline C4 & $22(11 \%)$ & $18(21 \%)$ & $40(14 \%)$ \\
\hline C5 & $9(5 \%)$ & $4(4 \%)$ & $13(5 \%)$ \\
\hline C6 & $5(3 \%)$ & $4(4 \%)$ & $9(3 \%)$ \\
\hline Всього & 192 & 87 & 279 \\
\hline
\end{tabular}

Програма передопераційної діагностики включала збір скарг на предмет наявності типових симптомів варикозної хвороби ніг і фізикальне обстеження для оцінки наявності і ступеня варикозного розширення вен ніг. Доплер-ультразвукове сканування в кольоровомута спектральному режимах було виконано у всіх пацієнтів для оцінки вертикального ретроградного кровотоку по стовбурах великої і малої підшкірних вен, а також виявлення горизонтального рефлюксу з неспроможних перфорантних вен. Кількісно венозна недостатність визначалася в разі пульсової хвилі ретроградного кровотоку тривалістю понад 500 мс після маневру мануальної компресії гомілки. Розмітка мережі підшкірних вен 3 маркуванням ключових точок (передбачуваних місць пункції вен, вузлів поділу столів і відходження притоків, вариксів і перфорантних вен) виконувалася безпосередньо перед операцією в положенні пацієнта стоячи. Від усіх пацієнтів було отримано письмове інформовану згоду стандартної форми актуального державного зразка; додатково, а також був запропонований опитувальник 3 хронічної венозної недостатності (CIVIQ). Збір даних, аналіз і розрахунки проводилися 3 використанням розширеного пакету програми Microsoft Excel 2016.

Післяопераційна консервативна терапія включала в себе курс флеботоніків (діосмінгесперидиновий комплекс 1000 мг на добу) протягом 60 днів і препарати НПЗ3 за потребою. Рівномірна еластична компресія досягалася за допомогою застосування ліцензованого госпітального компресійного трикотажу II класу компресії (22 32 мм рт. ст.) протягом від 14 до 28 діб.

Усі пацієнти проходили контрольну перевірку через 7 днів, 1 та 6 місяців, і потім кожні півроку. Фізикальне обстеження i кольорове дуплексне сканування оперованої кінцівки виконувалося для оцінки якості оклюзії ВПВ і можливого рефлюксутареканалізації. Пацієнтів просили заповнити анкету CIVIQ через 1 і 6 місяців після операції, що було визначено як post-CIVIQ-1 i post-CIVIQ-2 результати, відповідно.

Опитувальник 3 хронічної венозної недостатності (CIVIQ) використовувався для оцінки якості життя пацієнта (ЯЖ), спираючись на 20 ключових пунктів, розподілених на 4 групи (больовой синдром, фізичний, психологічний і соціальний стан).
По кожній із них запропонована кількісна оцінка інтенсивності даного показника від 1 до 5. Відповідно, мінімальний загальний бал - 20, що говорить про відмінну якість життя, а максимальний 100, що відображає дуже поганий загальний стан людини [9].

Результати досліджень та їх обговорення.

Формалізований план операчіi

Фізичний і психологічний комфорт пацієнта досягався шляхом вибору оптимального і компромісного положення на столі 3 урахуванням анатомічних особливостей тіла; метою було положення на спині з маневром Тренделенбурга. В рамках концепції малоінвазивної флебології, все втручання зводилося до черезшкірних варіантів; всі етапи операції контролювалася за допомогою інтраопераційного УЗ контролю безпосереднього хірургом. Операційна тактика передбачала принципове використання місцевої навігованої тунельної тумесцентной анестезії холодним розчином лідокаїну $0,1 \%$ уфасціальній оболонці стовбура підшкірної вени. Доступ до просвіту вени здійснювався за методикою Сельдингера в місці виходу стовбура вени 3-під фасції Томпсона. Установка інтрод’юсеру відповідного діаметру і проведення ефекторної частини генератора випромінювання здійснювалася відповідно до класичної методики під ультразвуковим контролем. Для пацієнтів контрольної групи лазерне оптоволокно позиціонувалося в 20 мм від сафено-феморальногоспівустя. Стандартна потужність на стегні встановлювалася на рівні 9-10 Ватт, що за умови рівномірної концентричної компресії за рахунок тунельованоготумесценту і зовнішнього стискання датчиком апарату УЗД при постійній лінійній швидкості екстракції світловоду забезпечувало розрахункову лінійну щільність енергії 5 Вт / мм. У пацієнтів досліджуваної групи наконечник електрода для ендовенозного електрозварювання позиціонувався в аналогічній точці. 3 огляду на те, що конструкційні та робочі особливості апарату передбачають регулювання ступеня деструкції стінки вени спираючись на іiі біофізичні параметри електропровідності й електроопору в режимі реального часу, що передаються по контуру зворотного зв'язку до керуючого модулю пристрою-генератора, тривалість експозиції елект- 
рода визначалася автоматично, а тракція ефекторної частини була дискретною і пропорційною довжині робочої поверхні. Візуальний контроль процесу коагуляції в обох групах здійснювався за допомогою ультразвукового контролю, орієнтуючись на ехо-ознаки облітерації вени (поява неоднорідного гіперехогенного вмісту в просвіті спазмованої судини). Варикозно розширені притоки підшкірних вен були виділені і ліговані за методикою Вараді. Перфорантні вени на стегні і гомілки, в залежності від їх анатомічної конфігурації, були ліквідовані за допомогою лазерної термоабляції із застосуванням торцевого оптоволокна або ліговані через мікродоступи.

Безпосередні і віддалені результати

У результаті оперативного лікування було прооперовано 279 пацієнтів із варикозним розширенням вен нижніх кінцівок. При цьому односторонній процес був зафіксований у 199 осіб (114 осіб з правобічною локалізацією і 85 - 3 лівосторонньою); у 80 пацієнтів захворювання було виявлено на обох ногах. 3 огляду на анатомічні особливості кожної кінцівки в контексті оперативного підходу, було прийнято рішення приймати одну кінцівку 3 діагностованим варикозним розширенням вен за одиницю спостереження і лікування. Відповідно, було проведено втручання на 359 нижніх кінцівках у пацієнтів 3 варикозною хворобою ніг.

Контроль лікування проводився за допомогою опитування та УЗ-контролю інтраопераційно i через 7 днів, 1, 6 місяців після операції. Як критерій був обраний параметр повноти облітерації неспроможного сегмента магістральних підшкірних вен. Результати були згруповані через 6 місяців наступним чином: «відмінно» - в післяопераційному періоді реканалізація стовбура не спостерігалася, «задовільно» - спостерігалася сегментарна реканалізація без гемодинамічно значущого рефлюксу крові по стовбуру, «незадовільно» гемодинамічно значущий рефлюкс крові по стовбуру (таблиця 3).

Таблиця 3

Об'єктивні результати лікування

\begin{tabular}{|l|l|l|}
\hline & \multicolumn{1}{|c|}{1 група } & \multicolumn{1}{|c|}{2 група } \\
\hline Відмінно & $189(96 \%)$ & $87(100 \%)$ \\
\hline Задовільно & $8(4 \%)$ & - \\
\hline Незадовільно & - & - \\
\hline Всього & 192 & 87 \\
\hline
\end{tabular}

Як критерій порівняння обрані тільки результати «відмінно». У післяопераційному періоді (6 місяців) частота випадків часткової реканалізації стовбура ВПВ на стегні в 1 групі становила 4\%, у другій $-0 \%$ ( $>>0,05$ по параметру $\chi 2)$. У всіх випадках реканалізації в першій групі рецидив спостерігався в басейні великої підшкірної вени; при цьому діаметр пригирлової ділянки склав понад 21 мм.

Усі пацієнти були виписані додому в день операції. Не було зафіксовано жодних післяопераційних ускладнень, таких як гематоми, неврити, опіки шкіри, перифлебіти, тромбози глибоких вен. Було відзначено вісім випадків локальних синців внаслідок флебектомії або тумесцентної анестезії; при цьому були зафіксовані випадки післяопераційного болю. Повне спостереження було виконано у 160 (94\%) пацієнтів. Через 1 місяць в обох групах у 13 пацієнтів відзначалася тимчасова легка болючість, ще у 4 парестезії на гомілці; анамнез даних пацієнтів був обтяжений наявністю цукрового діабету; у 7 пацієнтів загальної вибірки зберігалася симпто- матика ХВН у вигляді важкості в гомілках при УЗ-ознаках ліквідованого ретроградного кровотоку по підшкірних венах; у даних хворих варикозне розширення вен ніг поєднувалося 3 ліподерматосклерозу гомілок. Повна оклюзія підшкірних вен була зафіксована на рівні 96\% протягом 1 та 6 місяців в 1 групі і 100\% в другій, що продемонстровано при дуплексному скануванні. У восьми пацієнтів після ЕВЛК була зафіксована часткова проксимальна (<20 cм) реканалізація БПВ.

Середній бал до анкетування CIVIQ у першій групі склав $78,7 \pm 4,1$, а в другій 77,3 $\pm 3,6$ ( $>0,05)$. Надалі при аналізі динаміки загального і часткових параметрів якості життя в обох групах простежувалися статистично значущі зміни через 28 діб після проведеного лікування в порівнянні 3 передопераційними результатами; незначне поліпшення практично за всіма параметрами спостерігалося при повторному огляді через 6 місяців. На жодному з етапів не виявлено статистичного переваги за однією 3 методик (табл. 4). 
Бали CIVIQ, зареєстровані до операції і через 1 і 6 місяців спостереження

\begin{tabular}{|l|l|l|l|l|}
\hline & Пре-CIVIQ & пост-CIVIQ-1 & пост-CIVIQ-2 & р-значення \\
\hline Біль & & & & \\
1 група & $18,7 \pm 3,1$ & $7,7 \pm 2,3$ & $5,9 \pm 1,4$ & 0,001 \\
2 група & $17,6 \pm 1,2$ & $6,7 \pm 1,1$ & $6,5 \pm 1,2$ & 0,001 \\
\hline Фізичний стан & & & & \\
1 група & & & \\
2 група & $31,1 \pm 1,9$ & $14,9 \pm 2,5$ & $12,4 \pm 2,0$ & 0,001 \\
& $28,9 \pm 2,4$ & $13,3 \pm 1,6$ & $12,8 \pm 1,7$ & 0,001 \\
\hline Психологічний стан & & & & \\
1 група & & & \\
2 група & $17,7 \pm 1,1$ & $9,4 \pm 0,9$ & $6,8 \pm 1,7$ & 0,001 \\
& $18,4 \pm 2,1$ & $8,5 \pm 1,4$ & $7,1 \pm 1,2$ & 0,001 \\
\hline Соціальний стан & & & & \\
1 група & $11,2 \pm 2,0$ & $7,1 \pm 1,1$ & $6,3 \pm 1,4$ & 0,001 \\
2 група & $12,4 \pm 1,4$ & $5,9 \pm 1,6$ & $6,2 \pm 1,5$ & 0,001 \\
\hline Загальний бал & & & & \\
1 група & $78,7 \pm 4,1$ & $39,1 \pm 3,4$ & $31,4 \pm 3,3$ & 0,001 \\
2 група & $77,3 \pm 3,6$ & $34,4 \pm 2,9$ & $32,6 \pm 2,8$ & 0,001 \\
\hline
\end{tabular}

Важливо відзначити позитивну динаміку клінічного перебігу виразок шкіри у пацієнтів усіх груп. Із 7 пацієнтів 3 активними трофічними ушкодженнями шкіри лише у одного не відбулося самостійне повне заміщення дефекту рубцевої тканиною протягом 3 місяців. Після повторної консультації онкологом і пластичним хірургом пацієнт був направлений на хірургічне лікування на базі комбустіологічних відділення. Такі результати вказують на те, що, незалежно від обраної методики лазерного хірургічного лікування, всі вони ефективно дозволяють ліквідувати трофічні значущі мікроциркуляторні зміни і повернути їх в межі критичних значень.

Обговорення. Малоінвазивні черезшкірні методики лікування варикозної хвороби нижніх кінцівок знаходять все більш широке застосування в протягом останніх 20 років. У контексті визначення ефективності лікування захворювання в залежності від його патофізіологічної основи ендовенозна термоабляція показує високу ефективність щодо стовбурових варіантів рефлюксу крові; безпечність і багатообіцяючі довгострокові результати роблять іï ефективною альтернативою класичним операціям відкритої венозної хірургії [10], [11].

Метою ендовенозної термоабляції є досягнення стійкої оклюзії просвіту судини шляхом докладання теплової енергії до ऑї стінки. Технічний успіх залежить від кількості енергії, що поглинається веною [12]. Цей процес, в свою чергу, в значній мірі визначається декількома факторами, загальна суть яких зводиться до рівномірного розподілу достатньої кількості тепла по цільовій ділянці [12]. У першу чергу, мова йде про фізичні принципи роботи апаратно-технічного оснащення хірурга. Часто використовувані на сьогоднішній день висо- кочастотні діодні лазери 3 довжиною генерованої хвилі 1300-1600 нм мають здатність підводити енергію до тканин 3 піком поглинання водною компонентою, викликаючи безпосереднє теплове ушкодження ендотеліальних клітин стінки вени [12], [14]. Питання кількості енергії, необхідної для видалення неспроможного сегмента судини, визначається його калібром. Літературні дані показують, що діодний лазер 1470 нм вимагає лінійної щільності енергії в межах 65-100 Дж / см, щоб викликати стійку оклюзію просвіту вени, що протягом 1 року спостереження досягається практично в $100 \%$ випадків $[10,12]$. Важливою складовою успіху проведеної процедури, що повністю залежить від кваліфікації хірурга, є анестезія; тумесцентний маневр забезпечує не тільки такі очевидні переваги, як аналгезія і термоізоляція перивенозних тканин, але і концентрична компресія венозної стінки до ефекторних частини генератора теплової енергії [11].

Істотним недоліком будь-лазерної методики $є$ збереження в тій чи іншій мірі спектру побічних ефектів (опіки, екхімози, періфлебіти, реканалізаціiі), пов'язаного з практичною складністю визначення рівноважної точки дози випромінювання, еквівалентної необхідній кількості тепла, що залежить від низки факторів: по-перше, неможливість перерахунку генерованої світлової енергії в теплову в умовах постійної нелінійної зміни стану ефекторних частини лазерного волокна і стінки посудини; по-друге, складність визначення повноти площі контакту стінки вени з лазерним оптоволокном і об'ємної щільності розподілу теплової енергії, що, в свою чергу, призводить до утруднення вибору швидкості екстракції світловода 3 просвіту судини; по-трете, відсутність конструктивної основи для реалізації контуру зворотного зв'язку 3 
генератором, що нівелює альтернативний спосіб калібрування дози випромінювання на одиницю цільової області шляхом вимірювання біофізичних параметрів електропровідності й електроопору деструктованих тканин судини. Методологічна варіабельність існуючого методу безпосередньо пов'язана 3 досвідом фахівців і розумінням ними нюансів процесу, що служить додатковим джерелом ускладнень.

У практичній діяльності лікаря-флеболога ця проблема вирішена шляхом встановлення допустимої для виконання ендовенозної лазерної коагуляції з використанням 1470 нмдіодного лазера i радіального волокна верхньої межі пригирлового діаметра підшкірної вени близько 20 мм і наступною рекомендацією підвищувати настороженість щодо можливості виникнення рецидиву і проведення профілактики при збільшенні діаметра цільового судини. При цьому референтні значення калібру судини понад 20 мм пов'язані з експоненційним зростанням ризику реканалізації, а тактика збільшення поглиненої дози за рахунок потужності або тривалості експозиції потенціює ризик травми перивенозних тканин.

Зазначені обставини обумовлюють актуальність пошуку нового методу термальної абляції 3 меншим нагріванням тканин і більш досконалим алгоритмом управління. На даний момент, метод ендовенозного електрозварювання (ЕВЕ3), розроблений багатопрофільною командою НМАПО ім. П.Л. Щупика на основі технології електрозварювання живих біологічних тканин, відповідає даним вимогам.
Простіший принцип трансформації електричної енергії в теплову, а також можливість саморегулювання тривалості експозиції робочої поверхні електрода в просвіті вени до моменту різкого зниження іiі електропровідності, що характеризує якісну зміну іiі складу і життєздатності, роблять процес дозо- і часонезалежним, а отже, більш ефективним, більш зручним і більш безпечним. При цьому, фізичні розміри електрода і такий принцип роботи дозволяють добиватися оклюзії стовбурів підшкірних вен великих діаметром, аж до 30 мм, без появи ознак рецидиву варикозної хвороби протягом 6 місяців післяопераційного спостереження.

Таким чином, EBE3 є безпечним і ефективним методом лікування хронічних венозних захворювань нижніх кінцівок, представляючи собою повноцінну альтернативу ендовенозної лазерної коагуляції при великих діаметрах вен. Для більш точної оцінки ризиків виникнення побічних ефектів, характерних для ендовенозних термальних методик, а також для визначення діапазону допустимого для проведення процедури діаметра неспроможною вени, необхідні подальші дослідження на різних клінічних групах пацієнтів 3 варіативними сценаріями перебігу хронічної венозної недостатності ніг і коморбидної патології.

Висновки. EBE3 $є$ ефективною альтернативою ЕВЛК з більш високим профілем безпеки і досконалим алгоритмом управління.

EBE3 дозволяє ефективно проводити черезшкірнувенектомію при варикозній хворобі нижніх кінцівок iз діаметром неспроможного сегмента підшкірної вени від 20 до 30 мм при мінімальному спектрі ускладнень.

Інформація про конфлікт інтересів. Автори заявляють про відсутність конфлікту інтересів при виконанні наукового дослідження та підготовці даної статті.

Інформація про фінансування. Автори гарантують, що вони не отримували жодних винагород у будь-якій формі, здатних вплинути на результати роботи.

Особистий внесок кожного автора у виконання роботи:

Чернуха Л.М. - розробка концепції і дизайну дослідження, аналіз отриманих даних, редагування, статистична обробка даних;

Чехлов М.В. - збір матеріалу дослідження, розробка дизайну дослідження, аналіз отриманих даних;

Рябоконь А.М. - збір матеріалу дослідження, аналіз отриманих даних, підготовка тексту статті;

Столярчук Е.А. - збір матеріалу дослідження, аналіз отриманих даних.

\section{Список використаної літератури}

1. NICE. Varicose veins in the legs. The diagnosis and management of varicose veins. 2013 July.

2. Brake Maresa, Lim Chung S., Shepherd Amanda C., Shalhoub Joseph, Davies Alun H. Pathogenesis and etiology of recurrent varicose veins. Journal of Vascular Surgery, 2013 March.57 (3): 860-868.

3. Eberhardt R.T., Raffetto J.D. Chronic venous insufficiency. Circulation. 2014;130(4):333-346.

4. BaliyanVinit, TajmirShahein, HedgireSandeep S., GanguliSuvranu, PrabhakarAnandM. Lower extremity venous reflux. CardiovascDiagnTher. 2016 Dec; 6(6): 533-543.doi: 10.21037/cdt.2016.11.14

5. Lakhanpal S. Lower extremity venous insufficiency MUST be evaluated and treated as apart of 'Infradiaphragmatic venous disease'. Venous Review. 2015 June; 8 (2): 1-11.

6. Bishawi M, Bernstein R, Boter $M$ et al. Mechanochemical ablation in patientswithchronic venous disease: a prospective multicenter report. Phlebology. 2014 Jul;29(6): 397-400.

7. Biemans A.A, Kockaert M, Akkersdijk G.P. et al. Comparing endovenous laser ablation,foamsclerotherapy, and conventional surgery for great saphenous varicose veins. J Vasc Surg2013; 58(3): 727-734.

8. Malskat W. S. J. et al. Randomized clinical trial of endovenouslaserablation versus steam ablation (LAST trial) for great saphenous varicose veins. BJS. 2014August; 101 (9): 1077-1083. doi: 10.1002/bjs.9580. 
9. Hirokawa Masayuki, KuriharaNobuhisa. Comparison of Bare-Tip and Radial Fiber inEndovenous Laser Ablation with $1470 \mathrm{~nm}$ Diode Laser. Ann Vasc Dis. 2014; 7(3): 239-245.doi: 10.3400/avd.oa.14-00081.

10. VourliotakisGeorgios, SahsamanisGeorgios, Evagelidis Paschalis, AivatidiChristina.Endovascular laser treatment of incompetent saphenous veins using the $1470 \mathrm{~nm}$ diode laser andradial fiber. Ann Med Surg (Lond). 2018 Jan; 25: 12-16. doi: 10.1016/j.amsu.2017.12.002.

11. Bard S., Goldberg DJ. Complications of vascular laser treatment. Laser treatment ofvascular lesions. AesthetDermatol. Basel, Karger, 2014. 1: 121-142.

12. Saha S., Tiwari A., Hunns C., Refson J., Abidia A. Efficacy of topical local anaesthesiatoreduce perioperative pain for endovenous laser ablation of varicose veins: a double-blindrandomized controlled trial. Ther. Adv. Cardiovasc. Dis. 2016;10(4):251-255.

Стаття надійшла до редакції: 10.01 .2020 р. 